\title{
PERCEPTIONS OF ADOLESCENTS STUDENTS ON THE CONSUMPTION OF DRUGS: A CASE STUDY IN LIMA, PERU
}

\author{
Hilda Luz Bolaños Gil ${ }^{1}$ \\ Débora Falleiros de Mello \\ Maria das Graças Carvalho Ferriani ${ }^{3}$ \\ Marta Angélica Iossi Silva ${ }^{4}$
}

Bolaños Gil HL, Mello DF, Ferriani MGC, Silva MAI. Perceptions of adolescents students on the consumption of drugs: a case study in Lima, Peru. Rev Latino-am Enfermagem 2008 maio-junho; 16(especial):551-7

The consumption of drugs has increased worldwide and has become a public health problem, affecting particularly adolescents. This study aimed to identify the opinions of adolescent students on the use of drugs and drug users, in a school in Lima, Peru. It is a descriptive and cross-sectional study with a questionnaire selfapplied to 386 students. Data collected comprised students' personal data, their perception on the risk of drugs consumption, motivations, information on preventive interventions, drugs availability, opinion regarding drug users and their family, and social acceptance. Male gender was predominant. Most of the participants were unfavorable regarding risk perception and consumption motives, though, they were favorable towards information. We have a relevant role in explaining behaviors and also in implementing appropriate and efficient preventive and treatment programs.

DESCRIPTORS: adolescent; street drugs; substance-related disorders

\section{OPINIONES DE LOS ADOLESCENTES ESCOLARES SOBRE CONSUMO DE DROGAS: UN ESTUDIO DE CASO EN LIMA, PERÚ}

El consumo de drogas ha aumentado en todas las regiones del mundo, volviéndose un problema de salud pública, afectando especialmente a los adolescentes. Este estudio tiene como objetivos identificar las opiniones de los adolescentes escolares sobre el uso de drogas e identificar la opinión sobre el consumidor de drogas, en un colegio de Lima-Perú. Estudio descriptivo y transversal, se usó un cuestionario autoaplicado a 386 estudiantes. Se obtuvo datos personales del escolar, la percepción de riesgo del consumo de drogas, motivaciones, información acerca de medidas preventivas, disponibilidad de la droga, la opinión sobre el consumidor de drogas e la aceptación social y familiar al consumidor de drogas. Predomina el sexo masculino en las características personales. Al opinar sobre la percepción de riesgo la mayoría tiene opinión desfavorable de los motivos de consumo y esta a favor de la información. Tenemos un relevante papel tanto para explicar las conductas como para la puesta en práctica de programas adecuados y eficaces de prevención y tratamiento.

DESCRIPTORES: adolescente; drogas ilícitas; transtornos relacionados ao uso de substâncias

\section{OPINIÕES DE ADOLESCENTES ESTUDANTES SOBRE CONSUMO DE DROGAS: UM ESTUDO DE CASO EM LIMA, PERÚ}

O consumo de drogas tem aumentado em todas as regiões do mundo e tem se tornado um problema de saúde pública, afetando principalmente adolescentes. Este estudo tem como objetivo identificar as opiniões dos adolescentes em idade escolar sobre o uso de drogas e sobre o consumidor de drogas em uma escola de Lima, Peru. Estudo descritivo e transversal com questionário auto-aplicável a 386 estudantes. Foram obtidos dados pessoais dos estudantes, percepção de risco do consumo de drogas, motivações, informação sobre medidas preventivas, disponibilidade da droga, opinião sobre o consumidor de drogas e aceitação familiar e social do consumidor de drogas. O sexo masculino foi predominante. A maioria tem opinião desfavorável sobre a percepção de risco e sobre os motivos de consumo, e é a favor da informação. Temos um papel relevante na explicação de condutas assim como para por em prática programas adequados e eficazes de prevenção e tratamento.

DESCRITORES: adolescente; drogas ilícitas; dependência de drogas

${ }_{3}^{1}$ Assistant Professor, Cayetano Heredia University, School of Nursing, Peru, e-mail: hbolanos@upch.edu.pe; ${ }^{2}$ Associated Professor, e-mail:defmello@eerp.usp.br Full Professor, e-mail: caroline@eerp.usp.br; ${ }^{4}$ PhD Professor, e-mail: maiossi@eerp.usp.br. University of São Paulo at Ribeirão Preto, College of Nursing, WHO Collaborating Centre for Nursing Research Development, Brazil 


\section{INTRODUCTION}

Over the last 30 years, the consumption of drugs has increased alarmingly all over the world, becoming a public health problem and the third scourge of mankind. The United Nations Organization indicates that $5.09 \%$ of the world population from 15 to 64 years old has already consumed drugs, and growing drug traffic on several continents affects about 200 million people in the world. This phenomenon is responsible for more than $50 \%$ of the crimes committed by young people, considering adolescents as a vulnerable group to the problem of illicit drugs consumption ${ }^{(1)}$.

The consumption of drugs constitutes one of the behaviors that are mostly perceived as a problem by society, since it affects especially adolescents. In the adolescence stage, there is high prevalence of drugs use. Due to its availability, nowadays, adolescents have to learn how to deal with drugs, making decisions about their consumption or abstinence.

Adolescents' growing need for autonomy makes them reject the protection of adults and face risk situations and behaviors, which can present a serious threat to their development. Their need to feel special can make them believe that they are invulnerable and, thus, that they will not suffer the most probable consequences of the risks they take. Young people who regularly drink and smoke have a high prevalence for trying other drugs and present more positive attitudes towards the consumption of illegal drugs ${ }^{(2)}$.

A study about drugs and crime ${ }^{(1)}$ defends that adolescents have started the consumption of illicit drugs earlier, and alcohol is the main problem. Likewise, the use of legal and illegal drugs is dangerously increasing among students. The consumption of marijuana was evidenced in 61,988 students, PBC in 35,143 students and 39,200 consumed cocaine. Legal drugs (alcohol and tobacco, illegal for minors though) were mentioned by 646,755 students. Another study ${ }^{(3)}$ about ecstasy, a synthetic drug for oral use with stimulant characteristics, indicated that secondary students unexpectedly reported high rates of consumption (6.9\%). The adolescent population of Peru corresponds to $29 \%$ of the entire national population, and approximately $70 \%$ of them live in urban areas $^{(4)}$.
The present study is justified since the last investigations performed in this area show that adolescents and young people consume some kind of illicit drug. This is primarily concerning because the start age is earlier for the so-called social drugs, i.e. alcohol and tobacco, due to this stage of emotional, physiological and psychological changes the adolescents face. Moreover, several risk factors are present (low school affection, having friends or relatives who consume some kind of drug or stressful situations), which favor curiosity to try these substances. Therefore, it is essential to know the opinion of young people about this consumption, in order to be able to implement intervention actions in basic prevention, aimed at reinforcing the protection factors and motivating the adolescents as agents of their own changes.

The purpose of this study was to identify the opinion of adolescent students about both the use and the user of drugs, at a school in Lima-Peru.

\section{METHODOLOGY}

This study presents descriptive and crosssectional features. It was performed at a public coeducational school that provides primary and secondary education, located in the surrounding area of Lima-Peru. The school has 17 groups from first to sixth grade (primary school) and from first to fifth grade (secondary school), for adolescents who live in a settlement called San Martin.

The study population consisted of students who complied with the following inclusion criteria: students who were enrolled at the school in 2007, according to the references of the school subdepartment; students who did not present any chronic or severe mental disease; and who voluntarily agreed to participate in the study. There were 470 students currently taking secondary education, from the first to the fifth grade, and who were between 12 and 19 years old, from both sexes.

The sample size was calculated through a proportional sampling formula, considering the number of students in each grade. The sample consisted of: first grade - 85 students from a population of 106; second grade - 84 out of 105; third grade - 76 out of 93 ; forth grade - 64 out of 75 ; fifth grade - 77 out of 95 students, totaling 386 students. The selection of subjects was random and systematic, 
using lists of students from each grade as a sampling framework. The initial number of each sample (per grade) was selected through a table of random numbers. Then, the students were systematically selected.

The present study used a self-applied questionnaire that was adapted from another study (5) and consisted of 35 items, divided in three sections. The first section comprised students' personal data. The second section, containing 25 items, included the students' opinions about the consumption of drugs (perception of risk in the consumption of drugs $=7$ items; motives that lead to the consumption of drugs $=6$ items; information about preventive interventions $=7$ items; drug availability $=5$ items). The third section dealt with the students' opinions about drugs users (4 items) and social and family acceptance of this person ( 6 items). Each of the items was evaluated through a four-point Likert scale for each direct (strongly agree, agree, disagree, strongly disagree) and inverted (strongly disagree, disagree, agree, strongly agree) answer. The students' total score was classified as favorable (favorable opinion towards drug use) or unfavorable (unfavorable opinion towards drug use).

The project was approved by the Research Ethics Committee at the Peruvian University Cayetano Heredia. Data collection was carried out after the authorization of the school board and coordinated with the teacher of each group, in order to have access and get closer to the students, and eventually apply the instrument. A code was designated to each questionnaire so as to preserve participants' identity. The instrument was applied individually, since the study subjects had previous knowledge about it and had signed an informed consent term.

Data analysis was performed based on descriptive statistics of the opinions obtained from the adolescents, establishing a discussion mediated by the emerging aspects of studies developed with students from other countries.

\section{RESULTS}

According to the questionnaire results, the percentage of women who attend secondary school is slightly higher than that of men, $44.25 \%$ versus $55.75 \%$. The age range of these students is mostly between 14 and 16 years old (54.93\%), and $46.9 \%$ of them live with their parents, whereas $53.1 \%$ live with their mothers only.
The analysis of the adolescents' opinions about the consumption of drugs indicated that $52.6 \%$ of them are unfavorable towards drug use, whereas $47.4 \%$ are favorable, as observed in Figure 1.

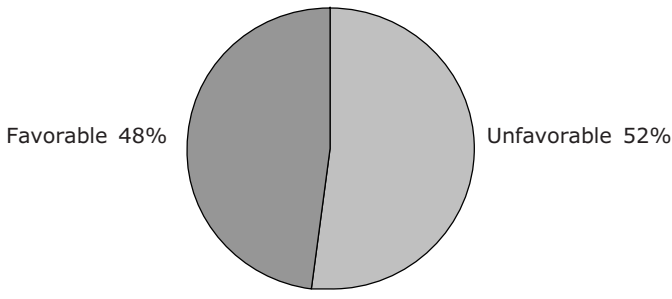

Figure 1 - Adolecent's opinions about the consumption of drugs. Co-educational school 3040 Lima, Peru 2007

Table 1 shows that $24 \%$ of the women were favorable towards drug use, and $26 \%$ were unfavorable, whereas $29 \%$ of men were favorable and $22 \%$ unfavorable.

Table 1 - Opinion of the adolescents towards drug use, according to their sex. National co-educational school 3040, Lima - Peru, 2007

\begin{tabular}{lcccccc}
\hline \multirow{2}{*}{ Sex } & \multicolumn{4}{c}{ Adolescents } \\
& Unfavorable & \multicolumn{2}{c}{ Favorable } & \multicolumn{2}{c}{ Total } \\
& No. & $\%$ & No. & $\%$ & No. & $\%$ \\
\hline Female & 99 & 26 & 91 & 24 & 190 & 49.3 \\
Male & 85 & 22 & 111 & 29 & 196 & 50.7 \\
Total & 184 & 48 & 202 & 53 & 386 & 100 \\
\hline
\end{tabular}

Regarding the perception of risk presented by the students, Table 2 indicates that $52.3 \%$ of them are unfavorable and $47.4 \%$ are favorable. Their motivation towards drug use was unfavorable for $53.6 \%$ and favorable for $46.4 \%$ of the adolescents.

In total, $38.6 \%$ of the interviewed students were favorable to information about drugs consumption and $61.4 \%$ were unfavorable. Regarding drug availability for consumption, $44.8 \%$ were unfavorable and $55.2 \%$ favorable.

Table 2 - Opinion of the adolescents about drugs use, according to consumption characteristics, National coeducational school 3040, Lima - Peru, 2007

\begin{tabular}{lcccccc}
\hline \multirow{2}{*}{ Consumption } & \multicolumn{2}{c}{ Unfavorable } & \multicolumn{2}{c}{ Favorable } & \multicolumn{2}{c}{ Total } \\
& No. & $\%$ & No. & $\%$ & No. & $\%$ \\
\hline Perception & 203 & 52.6 & 183 & 47.4 & 386 & 100 \\
Motivation & 207 & 53.6 & 179 & 46.4 & 386 & 100 \\
Information & 237 & 61.4 & 149 & 38.6 & 386 & 100 \\
Availability & 213 & 55.2 & 173 & 44.8 & 386 & 100 \\
\hline
\end{tabular}


Table 3 presents the opinions of the adolescent students about drugs users.

Table 3 - Opinion of the adolescents about drugs users. National co-educational school 3040, Lima - Peru, 2007

\begin{tabular}{|c|c|c|c|c|c|c|}
\hline \multirow{3}{*}{$\begin{array}{l}\text { Consumer and } \\
\text { Acceptance }\end{array}$} & \multicolumn{6}{|c|}{ Adolescents' Opinions } \\
\hline & \multicolumn{2}{|c|}{ Unfavorable } & \multicolumn{2}{|c|}{ Favorable } & \multicolumn{2}{|c|}{ Total } \\
\hline & No. & $\%$ & No. & $\%$ & No. & $\%$ \\
\hline About drugs users & 226 & 58.6 & 160 & 41.5 & 386 & 100 \\
\hline $\begin{array}{l}\text { Social and Family } \\
\text { Acceptance }\end{array}$ & 214 & 55.4 & 172 & 44.6 & 386 & 100 \\
\hline
\end{tabular}

When asked about drugs user, $58.6 \%$ of the students said they disapprove of this person, and $41.5 \%$ accepts young drug users. Similarly, most of them $(55.4 \%)$ are unfavorable towards social and family acceptance, whereas $46.5 \%$ are favorable.

Regarding the information students receive about drug consumption, the adolescents were favorable to receive this kind of information and manifested they would like to receive it from their teachers, followed by health professionals, a nurse in this case, and few of them would like to receive this information from their parents.

\section{DISCUSSION}

It is alarming that $53 \%$ of the adolescents under study are favorable to drugs consumption, and that $52.3 \%$ of them presented unfavorable opinions towards risk perception.

A study ${ }^{(6)}$ with the adolescent population of a co-educational secondary school, performed in Lima in 2002 , showed that $94.5 \%$ of the students stated that they consume drugs and that these substances are harmful to their health, while $2.5 \%$ said that they cause no harm and $6.5 \%$ that they are dangerous, which makes this stage more vulnerable to drugs.

Subjects with a greater risk of getting involved in these behaviors tend to overestimate the prevalence of consumption around them, as well as individual factors, such as experimental use determined by the adolescents' reasonable intent or decision on whether to start the consumption behavior or not. Primarily, the decision is affected by the students' attitude towards their own experimental use, which is influenced by the personal consequences (cost benefit) adolescents expect from this experimental use and the emotional value they attribute to these consequences. In this context, adolescents can have a positive attitude towards the consumption if their benefit expectations are higher than the consumption cost expectations. Secondly, the decision is affected by the adolescents' beliefs about the social rules regulating this consumption.

Adolescents perceive the risk of using drugs and seem to acknowledge young people as well as children as the most vulnerable group, who believe that using drugs is not dangerous. The risk perception is established through the subjects' reasonable decisions on whether to get involved in the consumption or not; beliefs; expectations; emotional values attributed to them; perception of expectations by significant people and self-efficacy, in other words, the control they have over drugs. Therefore, by not having a high risk perception, these subjects are in danger of starting to use drugs, as they believe that general drugs are not so dangerous and that they can quit anytime ${ }^{(7)}$.

The perception that nothing will happen and that they have control over the situation is a common characteristic among adolescents, which contributes to a reduced risk perception and increases the consumption of drugs. The Theory of Reasoned Action was used to get to know the adolescents' perception of the danger involved in the consumption of drugs for health. This theory aims to explain behaviors that are under the conscious control of the individuals, based on several determinants that precede and explain them. The behavior's immediate determinant is not the attitude itself, but the adolescents' intention to perform an action. On the other hand, the behavior intention has two pioneers that explain it: a strictly individual one, attitude towards behavior, and another one with social and collective characteristics, which refers to the individual sociocultural context, evidenced as a subjective rule ${ }^{(8)}$.

Regarding the adolescents' motivation to consume drugs, their use and abuse of psychoactive substances was found to be multifactorial, implying psychological, biological and social factors. These factors are generally related to the curiosity to achieve pleasure and satisfaction, relaxation from psychological tensions, to facilitate socialization, avoid social pressure from the group, social isolation, family dynamics, low self-esteem, inappropriate management of interventions about drugs, genetic influences and alcohol problems with relatives. Nevertheless, drugs' recreational character and adolescents' natural curiosity constitute one of the most influencing internal factors for experimental use $^{(9)}$. Likewise, just like any human being, adolescents 
are not homogenous beings. Instead, they have multiple characters that encourage them to live different experiences, challenging the unknown - as a reflection of the desire to know and break limits. Some of these experiences can meet these desires, for instance drugs.

Among the external factors, style is particularly important, since adolescence is influenced to choose their own style. In addition to this factor, there is the wish to belong to a group, the opinion of friends, the social model (adolescent world as product, reproduction of the adult world), easy accessibility to drugs, idol models and the possibility of an environment tending to the experimental use of drugs

In their own subjective "motivations", the wish for encouragement and risk seem to play an important role. A study developed by this team with adolescent students indicated that curiosity and the desire to try new sensations were the most frequent motivations marked for consumption. Another study found that the search for risk and adventure, the curiosity and the desire to overcome boredom are the most frequent reasons indicated when young people were asked about the reason for their criminal behavior ${ }^{(10)}$

The availability of information is a protection factor for not using, quitting or reducing damages due to drugs use. The object of this study was the availability and acceptance of information received in search of information regarding drugs. The most relevant means were the family, as the one who informs, by establishing dialogs about the issue; the teacher; friends and the health personnel, as well as communication media, such as radio, television and written media, and particularly media for young people $e^{(11-14)}$

Although young people realize their knowledge about drugs is getting broader, they require mainly reliable and credible information about all kinds of drugs and education about the prevention and reduction of damages, which coincides with the demands of young people from other European countries. Communication media need to promote attitudes and transmit knowledge about drugs and drug addiction properly. Otherwise, inappropriate information can increase consumption or aggravate society's reaction towards drug users, traumatize their parents and generate disdain, marginalization and the isolation of drug dependents

Young people have expressed their concern about the growing and early consumption of illegal drugs, which they relate to the substances' easy accessibility, which at a certain age may be even higher for legal drugs. Early experimental use of drugs, on the other hand, has been associated to use persistence. Among students from 13 to 14 years old, $22 \%$ stated that they have friends who had already tried illegal drugs, which supports young people's perception that contact with illegal drugs is happening earlier all the time. Money availability is associated to the consumption of tobacco, alcohol, Cannabis and other illegal drugs, as well as specifically to the consumption of cocaine by students ${ }^{(10)}$

Regarding the drug user, their opinion is similar to what is indicated by a study ${ }^{(15)}$ performed in Madrid, which shows that $26 \%$ of the students believe drug users are a result of the circumstances, $24.5 \%$ consider they are sick, $21.15 \%$ agree it is necessary to be hard on adolescents who consume drugs, $73 \%$ disagree with the idea that it is not possible to be understanding with drug dependents, since it is your problem. Similarly, $36.7 \%$ say drug dependents use these substances to evade their reality, and $36.2 \%$ state they are emotionally unstable. Regarding the support they should receive, $60.6 \%$ believe they need help, but not in jail.

Results concerning the adolescents' opinion about the family and social acceptance of the young consumer, in this study ${ }^{(15)}$, indicated that $56.0 \%$ would not mind to attend a consult with a young addict. Besides, $23 \%$ said they consider it right to accept them in their environment, even though they would not act in their favor, a total of $29.8 \%$ said they would feel dice uncomfortable, but they would not be active against them, $77.7 \%$ believe drug dependents and the care they demand are everyone's problem and responsibility ${ }^{(15)}$. These beliefs are partially established due to the perception of significant people's beliefs about the behavior an individual must present and, on the other hand, due to the individual's motivation to meet significant peoples expectations about them. In other words, adolescents can receive strong pressure to use drugs if they believe that their friends or family support the consumption, or if they believe there is consumption among their friends and adults in general.

Family cohesion is an important aspect for the family to accept a young consumer, considering its ability to work in an integrated and coherent way, as one articulated whole, benefiting individual development and favoring the feeling of belonging, in order to generate a protective effect ${ }^{(16)}$ A study ${ }^{(7)}$ found low levels of family cohesion in the Netherlands, 
in families whose children were drug dependents. Those parents who were more involved in the life of their adolescent children were always able to reduce the probability of drug consumption $r$ at least prevent their children from moving towards consumption behaviors of more abusive drugs ${ }^{(17)}$

In Argentina, the recent consumption of any illicit drug increases from $4.9 \%$ for students whose parents are more involved to $16.3 \%$ when parents are not involved at all. In Chile, there is the prevalence of $10.8 \%$ for students whose parents are more involved to $36.6 \%$ for those who consider their parents are not involved in their lives. In Ecuador, prevalence increases from $2.6 \%$ to $12 \%$, for students whose parents are more involved and not involved, respectively. In students from Paraguay, prevalence ranges from $2.1 \%$ for students whose parents are involved to $12.1 \%$ for parents who are not involved. In Peru, the prevalence identified was from $2 \%$ to $8.4 \%$ for students whose parents are more involved and not involved, respectively. Among students from Uruguay, recent consumption rates increase from $5.8 \%$ for students whose parents are more involved to $26.7 \%$ for parents who are not involved ${ }^{(7)}$

\section{FINAL CONSIDERATIONS}

This case study, performed at a school, revealed that the male gender predominates in the students' personal characteristics. When describing the adolescents' risk perception, most of them presented an unfavorable opinion, indicating knowledge about the consumption risk. Likewise, they have an unfavorable opinion about the consumption motives, and they are favorable to receiving information.

The unfavorable opinion about the availability of drugs is also highlighted in this investigation. Adolescents have an unfavorable opinion about the drug user, as well as the social and family acceptance towards the adolescent who consumes drugs.

The process of socialization with the family, friends, school and communication media is very important. The perception of risk and risk factors, added to idleness, leisure time and recreational life, are elements that must be considered in order to understand this problem. The authors believe people have a relevant role to play, both to explain this complex behavior and to implement appropriate and efficient prevention and treatment programs.

\section{ACKNOWLEDGEMENTS}

Acknowledgements to the Inter-American Drug Abuse Control Commission/CICAD of the SubSecretary of Multidimensional Security at the Organization of American States/OAS, the Brazilian Anti-Drugs Secretary/SENAD, faculty members at the University of São Paulo at Ribeirão Preto College of Nursing, WHO Collaborating Centre for Nursing Research Development, Brazil, to the population who participated in the studies and to the representatives from eight Latin-American countries who participated in the I and II On-Line Specialization Program for Research Capacity-Building on the Drugs Phenomenon-PREINVEST, offered in $2005 / 2006$ by the University of São Paulo at Ribeirão Preto College of Nursing, as a distance education course.

\section{REFERENCES}

1. Organización Naciones Unidas. Oficina contra las drogas y delito: tendencia mundial de drogas ilícitas. Viena (Austria); 2004. 2. Laespada T, Iraurgi I, Arostegui E. Factores de riesgo y de protección frente al consumo de drogas: hacia un modelo explicativo del consumo de drogas en jóvenes de la CAPV. Observatorio Vasco de Drogodependencias, Departamento de Vivienda y Asuntos Sociales. Vitoria-Gasteiz: Editorial Servicio Central de Publicaciones del Gobierno Vasco; 2004. 3. Vassilaqui A. Informe publicado por el Centro de Información y Educación para la Prevención del Abuso de Drogas (Cedro). Revisado 01.09.2006. Disponible in:< http:// www.spanish.xinhuanet.com/spanish/2006-09/01/content>. 4. Ministerio de Salud (Perú). Modelo de atención del adolescente. Lima (Perú): Ministerio de Salud; [actualizado en 6 septiembre 2006] Disponible in: <http://www.minsa.gob. Mais/3_Mais_Adolescente>.
5. Martínez PCC, Márquez JMR, García DM. Percepción de la farmacodependencia por estudiantes adolescentes de educación secundaria. Revista de Salud Pública y Nutrición 2002; 3(2):1-8.

6. Ministerio de Educación (Perú). Estudio epidemiológico sobre el consumo de drogas en la población escolar de secundaria de menores. Lima (Perú): Ministerio de Educación; 2002.

7. Comisión Interamericana para el Control del Abuso de Drogas (CICAD). Jóvenes y drogas en países sudamericanos: un desafío para las políticas públicas: primer estudio comparativo sobre uso de drogas en población escolar secundaria de Argentina, Bolivia, Brasil, Colombia, Chile, Ecuador, Paraguay, Perú y Uruguay. [Septiembre 2006] Disponible in: <http://www.cicad.oas.org>.

8. Salovey M, Rothman A. Acción razonada y reacción social: creencias sobre salud y comportamiento relativo a la salud. Lisboa: Psicologia Social da Saúde; 2003. 
9. Scivoletto S, Morihisa RS. Conceitos básicos em dependência de álcool e outras drogas na adolescência. J Bras Dependência Química 2001; 2 (Supl 1): 30-3.

10. Luengo MA, Romero JA, Gómez A, Guerra ML. La prevención del consumo de drogas y la conducta antisocial en la escuela: análisis y evaluación de un programa. Santiago de Compostela (España): Ministerio de Educación y Cultura; 1997. 11. Kelly KJ, Comello MLG, Hunn LCP. Parent-child communication, perceived sanctions against drug use and youth drug involvement. Adolescence 2002; 37(1):775-87. 12. Sanchez ZVM, Oliveira LG, Nappo SA. Razões para o não-uso de drogas ilícitas entre jovens em situação de risco. Rev Saúde Pública 2005; 39(4): 599-605.

13. Boyle MH, Sanford M, Szatmari P, Merikangas K, Offord $D R$. Familial influences on substance use by adolescents and young adults. Can J Public Health 2001; 92 (1):206-9.

14. Oliveira MR, Villar MA. Factores de riesgo para el consumo de alcohol en escolares de 10 a 18 años, de establecimientos educativos fiscales en la ciudad de La Paz - Bolivia (2003-2004). Rev Latino-am Enfermagem 2005; 13(special): $880-7$

15. Centro de Investigaciones Sociológicas (CIS). Percepción social de las drogas en la comunidad de Madrid. Estudio no 2.425. [Citado 2001 Julio]. Disponible in:<htpp// www.cis.es/cis/export/sites/default/rchivos/Marginales/ 2420_2439/Es24>.

16. Sanz M, Iraurgi I, Martínez-Pampliega A, Cosgaya L. Conflicto marital y consumo de drogas en los hijos. Adicciones [serial on line] 2006 [Citado 2006 Noviembre]; 18 (1): 3948. Disponible in:<http://www.adicciones.es $>$.

17. Galindo J, Alfaro I, Osso L, Mormontoy W. Vulnerabilidad familiar en el consumo de drogas en familias de adolescentes. Rev Psiquiatr Salud Mental Hermilio Valdizan 2004; I(1):3-35. 